\title{
Co-production of hydrogen and carbon nanofibers from methane decomposition over zeolite Y supported Ni catalysts
}

\author{
Md. Nasir Uddin ${ }^{a}$, W.M.A. Wan Daud ${ }^{\mathrm{a}, *}$, Hazzim F. Abbas ${ }^{\mathrm{b}}$ \\ a Department of Chemical Engineering, Faculty of Engineering, University of Malaya, 50603 Kuala Lumpur, Malaysia \\ ${ }^{\mathrm{b}}$ Department of Chemical Engineering, University of Nizwa, Al Dakulaya, Oman
}

A R T I C L E I N F O

Article history:

Received 10 July 2014

Accepted 25 October 2014

Available online 29 November 2014

\section{Keywords:}

Coproduction

Hydrogen

Carbon nanofiber

Zarbon natite Y

Supported $\mathrm{Ni}$

Methane decomposition

\begin{abstract}
A B S T R A C T
The objective of this paper is to study the influences of different operating conditions on the hydrogen formation and properties of accumulated carbon from methane decomposition using zeolite $\mathrm{Y}$ supported $15 \%$ and $30 \% \mathrm{Ni}$, respectively, at a temperature range between 500 and $650{ }^{\circ} \mathrm{C}$ in a pilot scale fixed bed reactor. The temperature ramp was showed a significant impact on the thermo-catalytic decomposition (TCD) of methane. An optimum temperature range of $550-600^{\circ} \mathrm{C}$ were required to attain the maximum amount of methane conversion and revealed that at 550 and $600^{\circ} \mathrm{C}$, catalyst showed longer activity for the whole studied of experimental runs. Additionally, at $550^{\circ} \mathrm{C}$, the methane decomposition is two times longer for $30 \% \mathrm{Ni} / \mathrm{Y}$ zeolite than that for $15 \% \mathrm{Ni} / \mathrm{Y}$ zeolite catalyst, whereas it is almost three times higher at $500{ }^{\circ} \mathrm{C}$. A maximum carbon yield of 614.25 and $157.54 \mathrm{~g}_{\mathrm{c}} / \mathrm{g}_{\mathrm{Ni}}$ were reported after end of the complete reaction at $600{ }^{\circ} \mathrm{C}$ with $30 \%$ and $15 \% \mathrm{Ni} / \mathrm{Y}$ zeolite catalyst, respectively. From BET, TPD, and XRD analysis, we had reported that how the chemistry between the TCD of methane and metal content of the catalysts could significantly affect the hydrogen production as well as carbon nano-fibers. TEM analysis ensured that the produced carbon had fishbone type structures with a hollow core and grew from crystallites of $\mathrm{Ni}$ anchored on the external surface of the catalysts and irrespective of the metal loadings, the whisker types of nano filaments were formed as confirmed from FESEM analysis. Nevertheless, the effect of volume hourly space velocity (VHSV) on the methane conversion was also investigated and reported that the methane conversion increased as VHSV and nickel concentration in Ni-Y catalysts increased. Additionally, the initial methane decomposition rate increases with VHSV and it has reverse and non-linear relevancy to the weight of $\mathrm{Ni} / \mathrm{Y}$ zeolite catalyst.
\end{abstract}

2014 Elsevier Ltd. All rights reserved.

\section{Introduction}

The idea of co-production of hydrogen and carbon nanomaterials from thermo-catalytic decomposition (TCD) of methane has been having a great mettlesome attention among the Scientists and Engineers around the earth. This is because it produces environmentally -benign hydrogen and carbon nanomaterials that seem to be a clean, halcyon and officious product in foreseeable future [1-3]. Both of the products are derived from the TCD of methane, according to the following equation at low temperatures ranging from 400 to $700{ }^{\circ} \mathrm{C}$ when the process associated with the schemes of metal catalysts [4]:

\footnotetext{
* Corresponding author. Tel.: +60 1111200713; fax: +60 379675319.

E-mail addresses: nasir_cep01@hotmail.com (Md. Nasir Uddin), ashri@um.edu.
} my (W.M.A. Wan Daud).

http://dx.doi.org/10.1016/j.enconman.2014.10.060 0196-8904/@ 2014 Elsevier Ltd. All rights reserved.
$\mathrm{CH}_{4} \rightarrow 2 \mathrm{H}_{2}(\mathrm{~g})+\mathrm{C}(\mathrm{s}) \quad \Delta \mathrm{H}^{0}=75.6 \mathrm{~kJ} / \mathrm{mol}$

Because of its lower cost selectivity, and much higher active site/ carbon capacities, Ni has been broadly assessed in manufacturing of hydrogen from methane decomposition as compared with the cobalt or iron $[5,6]$. Regards to catalytic materials, the use of zeolitic materials has of both fundamental and practical significance due to their well-defined pore distributions, high surface area and unique catalytic features as compared to traditional catalyst supported on alumina, silica-alumina, $\mathrm{CeO}_{2}$, peroviskite, active carbon, $\mathrm{La}_{2} \mathrm{O}_{3}$, and $\mathrm{MgO}$ [7]. The Y-zeolite has comparatively larger pores (Entry aperture of $0.74 \mathrm{~nm}$, and a diameter of $1.3 \mathrm{~nm}$ ) than the others such as HZSM-5 $(0.51-0.55 \mathrm{~nm} ; 0.51-0.55 \mathrm{~nm})$ and zeolite A $0.41 \mathrm{~nm}$ $1.1 \mathrm{~nm}$ ). Therefore, the introduction of nickel metals into $\mathrm{Y}$ zeolites by means of a suitable method such as impregnation or ionexchange, etc., would make it suitable for TCD of methane. However, the research work on Y zeolite supported Ni catalysts in hydrogen and carbon nanomaterial's production from TCD of methane is still 
very limited even though a great number of articles have already been disclosed the application of the metallic nickel catalysts on the activity of different support materials $[2,6,8]$.

The degree of hydrogen and carbon nanomaterials production from TCD of methane depend as much on the reactor operating conditions such as feeding rate, reaction temperature and volume hourly space velocity (VHSV), as on the type of textural characteristics of support materials, catalyst's composition, and the additive concentration. Inaba et al. [9] have pointed out that the catalyst optimization using silica and several types of zeolite supported $\mathrm{Ni}$ catalysts for hydrogen yields from methane cracking at $650^{\circ} \mathrm{C}$. They described that USY-zeolite supported Ni catalysts showed higher catalytic longevity's (owing to active for around $6 \mathrm{~h}$ ) as compared to silica supported Ni catalyst. The highest methane conversion was highlighted approximately $45 \%$. They cited that the quantity of solid acidity in the support was tending to be lower if nickel particles have a smaller diameter. The accumulated carbon (AC) was estimated to be higher on the surface of Ni-supported catalysts even after complete deactivation when the supports have a larger external surface area. Very similar results were reported by Ashok et al. [8] who found that the highest activity subjected to $\mathrm{Ni} / \mathrm{HY}$ catalyst $(12 \mathrm{~h})$ and higher activity of $955 \mathrm{~mol}_{\mathrm{H} 2} / \mathrm{mol}_{\mathrm{Ni}}$ compared to other tested support on HY, USY, $\mathrm{SiO}_{2}$ and SBA-15 at $5500^{\circ} \mathrm{C}$. At a temperature range between 750 and $900{ }^{\circ} \mathrm{C}$ and VHSV range between 3.0 and $18.0 \mathrm{Lg}^{-1} \mathrm{~h}^{-1}$ were set to investigate the methane decomposition for hydrogen yield using activated alumina and carbon as highlighted by Bai et al. [10]. At early of the decomposition reaction, the methane conversion was reflected maximum value around $25-35 \%$ for all types of used catalysts and thereafter, it started to decline progressively over the course of reaction stream $(2 \mathrm{~h})$. The catalytic activity took place primarily in the micropores that is confirmed from the change of pore size of activated carbon during the methane decomposition reaction. Apart from activated carbon textural properties, the activated alumina catalysts showed mesoporous nature that is subjected to the catalytic activity, resulting in a variation of carbon deposits and textural properties. Rely on the different precursors of activated carbon; two classes of AC can be appeared on the activated carbon either in the form of carbon filaments or agglomerates.

The work reported here emphasized at clarifying the influences of different operating conditions in a fixed bed reactor on hydrogen formation and properties of AC using two different Ni loading on the catalytic activity of $\mathrm{Y}$ zeolite catalyst. In addition, the structural and morphological features of the produced carbon and the textural features of the samples used are also examined for different operating parameters.

\section{Experimental Methodology}

\subsection{Experimental view and operating conditions}

Raw methane (99.9995\%) purchased from Linde Compressed and nitrogen (99.999\%) served by Air products were utilized in the experiment. The zeolite Y catalyst ( surface area $=650 \mathrm{~m}^{2} / \mathrm{g}, \mathrm{Si}$ / $\mathrm{Al}=10$ ) purchased from Tosoh Corporation, Japan and used it as in the form of impregnation with nickel metals. The catalysts preparation methods and experimental apparatus used are described in details elsewhere [3]. In each experimental run, typically $3 \mathrm{~g}$ of Ni/Y zeolite catalyst was loaded into the reactor. Then the reaction started with the flow of $1 \mathrm{~L} / \mathrm{min}$ of $\mathrm{CH}_{4}$ over the catalyst bed using $15 \%$ and $30 \% \mathrm{Ni} / \mathrm{Y}$ zeolite catalysts at $500,550,600$, and $650^{\circ} \mathrm{C}$, respectively. Before reaction, the catalyst is reduced by $20 \%$ hydrogen at $600^{\circ} \mathrm{C}$ (heating ramp was $10^{\circ} \mathrm{C} / \mathrm{min}$ ) in nitrogen for $2 \mathrm{~h}$ in order to obtain active metallic state in the catalyst and this is continued until system reached a set temperature. After that, a $1 \mathrm{~L} / \mathrm{min}$ of nitrogen gas was thoroughly flushed for another $1 \mathrm{~h}$ within the reactor before feeding the set $\mathrm{CH}_{4}$ flow rate. The reaction continued until the spontaneous hydrogen yield below $7 \%$. The percentage of methane conversion calculated from data obtained from outflow gas that was analyzed by an online gas analyzer (GA). Using GA, other than hydrogen, no gaseous products detected. A flow of nitrogen was purged through the reactor to cool down it to ambient temperature after the reaction, and the total amount of solid carbon measured by using the following equation:

$$
M_{c}(\%)=\left(\frac{w_{\text {tot }}-w_{\text {cat }}}{w_{\text {cat }}}\right) \times 100
$$

In Eq. (2), $w_{\text {tot }}$ and $w_{\text {cat }}$ represents the total and initial weight of the catalyst after and before reaction, respectively. This yield was also expressed in the form of $\mathrm{g}_{\mathrm{dep}} / \mathrm{g}_{\mathrm{Ni}}$.

\subsection{Characterization techniques}

In order to investigate the textural features of the catalysts and nanomaterials, the $\mathrm{N}_{2}$ physisorption technique was done using nitrogen as adsorbent at $77 \mathrm{~K}$ from the Micromeritics ASAP 2020 sorptometer. A Micromeritics TPD/TPR 2720 analyzer was used to characterize how $\mathrm{NH}_{3}$ molecules are strongly conjugated to the acid sites qualitatively. Firstly, a typical $0.50 \mathrm{~g}$ catalyst samples was heated in a flow system at a $30 \mathrm{~mL} / \mathrm{min}$ helium flow rate with a temperature ramp of $10^{\circ} \mathrm{C} / \mathrm{min}$ increase to $25-780^{\circ} \mathrm{C}$, and at this temperature, the system stays for $30 \mathrm{~min}$. Next, a helium flow of $20 \mathrm{~mL} / \mathrm{min}$ was performed to reduce the catalyst until cool it to $210^{\circ} \mathrm{C}$. Thereafter, ammonia was streamed on the samples for $20 \mathrm{~min}$. In order to reduce the physisorbed elements from the samples, a purging procedure was introduced with helium for another one hour. The chromatograms were obtained from the signal processing of thermal conductivity detector using the temperature ramp of $10^{\circ} \mathrm{C} / \mathrm{min}$ from $210^{\circ} \mathrm{C}$ to $750^{\circ} \mathrm{C}$.

$\mathrm{X}$-ray diffraction (XRD) patterns of the fresh and spent catalysts were determined on a Rigaku miniflex using $\mathrm{Cu} K \alpha$ radiation with a generator voltage and current of $45 \mathrm{kV}$ and $40 \mathrm{~mA}$, respectively. Using global Scherrer equation (based on the half-width of diffraction lines assigned to planes (111), (200), and (220) for $\mathrm{NiO}$ and $\mathrm{Ni}$ phase, respectively), the average crystallite size $\left(D_{\text {avg }}\right)$ was obtained as follows [11]:

$D_{\text {avg }}=\frac{0.9 \lambda}{\beta \cos \theta}$

where 0.9 is the Scherrer constant, $\beta$ is the full width at half maxima (in radians) of a reflection located at $2 \theta$.

The morphological structure and the diameter distribution of the catalysts and carbon nanomaterials were performed on a Field Emission Scanning electron microscopy, FESEM (QUANTA 450 FEG) and transmission electron microscopy, TEM (Hitachi HT-7700). Totally, more than 50 carbon nanofibers (CNFs) was measured on the TEM images, and the result reported as the arithmetic mean value of the data.

\section{Results and discussion}

3.1. Thermal decomposition of Methane over zeolite $\mathrm{Y}$ supported $\mathrm{Ni}$ catalysts

3.1.1. Effect of temperature ramp on TCD of methane

In Table 1, we report the reaction yields in terms of the three main conjugating reactions (initial $\mathrm{H}_{2} \%$, initial $\mathrm{CH}_{4} \%, \mathrm{H}_{2}$ formation rate, and average carbon formation rate, ACFR) at the temperature range of $500-650{ }^{\circ} \mathrm{C}$. In this experiment, the hydrogen formation rate (HFR) was presented in terms of average hydrogen formation 
Table 1

Experimentally obtained results from methane decomposition over Ni-supported $\mathrm{Y}$ zeolite under selected reaction conditions.

\begin{tabular}{|c|c|c|c|c|c|c|c|c|c|c|}
\hline \multirow{3}{*}{$\begin{array}{l}\text { Run } \\
\text { no. }\end{array}$} & \multirow{3}{*}{$\begin{array}{l}T \\
\left({ }^{\circ} \mathrm{C}\right)\end{array}$} & \multirow{3}{*}{$\begin{array}{l}\text { Initial } \mathrm{H}_{2}{ }^{\mathrm{a}} \\
\text { (\%) }\end{array}$} & \multirow{3}{*}{$\begin{array}{l}\text { Initial } \\
\mathrm{CH}_{4}{ }^{\mathrm{b}} \text { (\%) }\end{array}$} & \multicolumn{6}{|c|}{ Behavior of $\mathrm{H}_{2}$ production with respect to time } & \multirow{3}{*}{$\begin{array}{l}\text { ACFR, }(\mathrm{mmol} / \\
\left.\left(\mathrm{g}_{\mathrm{cat}} \mathrm{min}\right)\right) \\
\text { After end of complete } \\
\text { reaction }\end{array}$} \\
\hline & & & & \multicolumn{2}{|c|}{ At time $=10 \mathrm{~min}$} & \multicolumn{2}{|c|}{ At time $=26 \mathrm{~min}$} & \multicolumn{2}{|c|}{ At time $=60 \mathrm{~min}$} & \\
\hline & & & & $\begin{array}{l}\text { THF (mol/ } \\
\left.\mathrm{g}_{\text {cat }}\right)\end{array}$ & $\begin{array}{l}\text { AHFR }(\mathrm{mmol} / \\
\left.\left(\mathrm{g}_{\text {cat }} \cdot \mathrm{min}\right)\right)\end{array}$ & $\begin{array}{l}\text { THF (mol/ } \\
\left.\mathrm{g}_{\text {cat }}\right)\end{array}$ & $\begin{array}{l}\text { AHFR }(\mathrm{mmol} / \\
\left.\left(\mathrm{g}_{\text {cat }} \mathrm{min}\right)\right)\end{array}$ & $\begin{array}{l}\text { THF (mol/ } \\
\left.\mathrm{g}_{\text {cat }}\right)\end{array}$ & $\begin{array}{l}\text { AHFR }(\mathrm{mmol} / \\
\left.\left(\mathrm{g}_{\text {cat. }} \mathrm{min}\right)\right)\end{array}$ & \\
\hline \multicolumn{11}{|c|}{ With $15 \%$ Ni-supported Y zeolite catalysts } \\
\hline 1 & 500 & 19.09 & 10.52 & 36.14 & 4.88 & 81.08 & 4.67 & 161.54 & 4.17 & 1.35 \\
\hline 2 & 550 & 30.27 & 17.73 & 59.35 & 8.56 & 133.33 & 8.19 & 270.70 & 7.41 & 2.06 \\
\hline 3 & 600 & 36.32 & 22.11 & 70.21 & 10.46 & 159.34 & 10.11 & 331.55 & 9.39 & 2.87 \\
\hline 4 & 650 & 41.02 & 25.76 & 80.62 & 12.40 & 182.91 & 11.97 & 372.34 & 10.82 & 3.61 \\
\hline \multicolumn{11}{|c|}{ With $30 \%$ Ni-supported Y zeolite catalysts } \\
\hline 5 & 500 & 18.08 & 9.91 & 39.36 & 5.36 & 84.47 & 4.89 & 172.40 & 4.47 & 1.79 \\
\hline 6 & 550 & 34.85 & 20.82 & 70.41 & 10.49 & 159.23 & 10.10 & 324.58 & 9.17 & 2.45 \\
\hline 7 & 600 & 48.85 & 31.57 & 95.27 & 15.36 & 216.31 & 14.82 & 449.15 & 13.66 & 4.32 \\
\hline 8 & 650 & 58.58 & 41.67 & 116.65 & 20.22 & 265.80 & 19.57 & 557.19 & 18.16 & 6.01 \\
\hline
\end{tabular}

${ }^{\text {a }}$ The initial hydrogen (\%) was derived from the curve fitting of instantaneous hydrogen yield versus reaction time using a proper $n$th order polynomial equation with regression coefficients greater than 0.99 and then substituted of time equal to zero in the right hand side of the curve fitting equation.

$\mathrm{b}$ The initial methane (\%) was calculated exactly as the same method as for initial hydrogen (\%) except, in this case, using the methane conversion against reaction time curve fitting.

rate (AHFR), and total hydrogen formation (THF) at three representative reactions times for making a concise assessment of TCD of methane over $\mathrm{Ni} / \mathrm{Y}$ zeolite catalyst. Reported data in Table 1 indicates that the initial $\mathrm{H}_{2}$ and $\mathrm{CH}_{4}$ increase for both kinds of Ni-supported $\mathrm{Y}$ zeolite catalyst as temperature increases. It can be observed from Table 1 that the highest initial $\mathrm{H}_{2}$ and $\mathrm{CH}_{4}$ have to be found $41.02 \%$ and $25.76 \%$, for $15 \% \mathrm{Ni} / \mathrm{Y}$ zeolite catalyst whereas the value of $58.58 \%$ and $41.67 \%$ was noted for $30 \% \mathrm{Ni} / \mathrm{Y}$ zeolite catalyst, respectively at $650{ }^{\circ} \mathrm{C}$. This is reasonable because TCD of methane is an endothermic reaction, so equilibrium methane conversion is increased with an increase in temperature [5]. However, the methane decomposition showed a relatively shorter activity for more than 2 and $3 \mathrm{~h}$ for $15 \%$ and $30 \% \mathrm{Ni} / \mathrm{Y}$ zeolite catalyst, respectively (Fig. 1). At $600^{\circ} \mathrm{C}$, the decomposition rate is lesser than at $650^{\circ} \mathrm{C}$, but shows higher catalytic activity for more than 5 and $11 \mathrm{~h}$ before becomes negligible for $15 \%$ and $30 \% \mathrm{Ni} / \mathrm{Y}$ zeolite catalyst, respectively. As can be noticed from Fig. 1, that the methane decomposition at $550{ }^{\circ} \mathrm{C}$ has maximum catalytic activity as compared with $600{ }^{\circ} \mathrm{C}$ and it endures for more than 6 and 12 for $15 \%$ and $30 \% \mathrm{Ni} / \mathrm{Y}$ zeolite catalyst, respectively. On the other hand, at $500{ }^{\circ} \mathrm{C}$, the decomposition of methane showed lower stability for more than 2 and $7 \mathrm{~h}$ for $15 \%$ and $30 \% \mathrm{Ni} / \mathrm{Y}$ zeolite catalyst, respectively; before falling to almost zero. The above results indicate that at $550^{\circ} \mathrm{C}$, the methane decomposition is two times longer for $30 \% \mathrm{Ni} / \mathrm{Y}$ zeolite than that for $15 \% \mathrm{Ni} / \mathrm{Y}$ zeolite catalyst, whereas it is almost three times higher at $500{ }^{\circ} \mathrm{C}$. Interestingly, at 550 and $600^{\circ} \mathrm{C}$, catalyst showed longer activities for the whole studied of experiment runs. This is notifying that the TCD of methane on $\mathrm{Ni} / \mathrm{Y}$ zeolite catalyst required an optimum temperature and in this case it is ranged from 550 to $600{ }^{\circ} \mathrm{C}$. As can be visualized from Fig. 1, there was no induction period at which methane conversion pass through a maximum level [12]

In accordance with the above results, Inaba et al. [9] has demonstrated that Ni-supported on USY zeolite shows the longer activity for more than $6 \mathrm{~h}$ among the others. Very similar results were reported by Ashok et al. [8] who found that highest activity subjected to $30 \% \mathrm{Ni} / \mathrm{HY}$ catalyst $(12 \mathrm{~h}$ ) and higher activity of 955 $\mathrm{mol}_{\mathrm{H} 2} / \mathrm{mol}_{\mathrm{Ni}}$ compared to other tested support on HY, USY, $\mathrm{SiO}_{2}$ and SBA- 15 at $550{ }^{\circ} \mathrm{C}$. With $15 \% \mathrm{Ni} / \mathrm{HY}$ catalysts, they found hydrogen yield of $993 \mathrm{~mol}_{\mathrm{H} 2} / \mathrm{mol}_{\mathrm{Ni}}$, whereas $370 \mathrm{~mol}_{\mathrm{H} 2} / \mathrm{mol}_{\mathrm{Ni}}$ of hydrogen production was noticed for $60 \% \mathrm{Ni} / \mathrm{HY}$ catalysts. Michalkiewicz and Majewska [13] reported about 55\% of hydroge was produced using the Ni/ZSM-5 (300) catalysts from methane decomposition at a temperature range of $650^{\circ} \mathrm{C}$ and $700{ }^{\circ} \mathrm{C}$. The highest carbon yield was reported to be approximately $32 \mathrm{wt} \%$ a $700{ }^{\circ} \mathrm{C}$ by using Ni particle size of about $30-60 \mathrm{~nm}$ depending on the temperature. In comparison to these results, ours results is a quite bit lower but our study examined the temperature range which is much lower than do Michalkiewicz and Majewska research.

The above discussion established that the carbon deposition is directly related to the metal content of the catalyst. The highly distribution of nickel species into the zeolite Y cages and likely more significantly, the synergistic influence between the microporous surfaces of zeolite $\mathrm{Y}$ and metallic nickel were considered to be the reasons for higher catalytic performance of $30 \% \mathrm{Ni} / \mathrm{Y}$ zeolite [7]. A greater electron density on the surface of metallic nickel and increment of the retention capacity of hydrogen in the $\mathrm{Ni} / \mathrm{Y}$ zeolite catalysts were caused from the synergistic effects due to
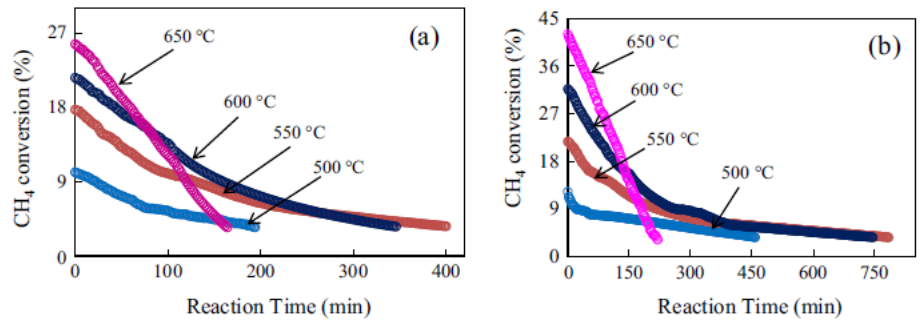

Fig. 1. Representation of methane conversion as a function of reaction time on stream for (a) $15 \% \mathrm{Ni} / \mathrm{Y}$ zeolite catalyst, and (b) $30 \% \mathrm{Ni} / \mathrm{Y}$ zeolite catalyst. 
it may cover the interactions between the higher ionic microporous surface of zeolite $Y$ and the nickel particles. Eventually, a rapid catalytic deactivation of $30 \% \mathrm{Ni} / \mathrm{Y}$ zeolite was observed in the course of decomposition reaction due to a large number of nickel species on the catalysts surface resulting in a carbon accumulation over the active metal species. Accordingly, it is believed that much more carbon can be generated only when the outer surface area of the catalysts covered by metal particles and these sites are very much elevated when metal is deposited by impregnation method [7].

According to stoichiometry calculation of methane decomposition, the AHFR was computed assuming that only hydrogen and carbon were produced. The THF was determined by summing on the total instantaneous hydrogen formed per initial Ni-supported Y zeolite catalyst mass. It can be seen from Table 1 that as time proceeds, THF is increased as temperature increased while AHFR is almost straightly decreased for both type of catalyst. This is more likely that TCD of methane with respect to time increase the deposition of carbon on the $\mathrm{Ni} / \mathrm{Y}$ zeolite catalyst surface. Additionally, the AHFR increased significantly with increasing temperature but reduced the catalyst lifetime. This is reasonable because at $650{ }^{\circ} \mathrm{C}$, the deactivation is rapid and results in a complete loss of catalyst activity due to solid carbon formation rate was higher rather than the carbon removal rate from the active surface, which led to the carbon accumulation on the surface and thus, AHFR was reduced over the course of decomposition reaction. On the other hand, the ACFR also increases as the temperature increases from 500 to $650{ }^{\circ} \mathrm{C}$ as shown in Table 1 .

Fig. 2(a) and (b) shows the accumulated carbon (AC) against time plot for temperatures of $500,550,600$ and $650{ }^{\circ} \mathrm{C}$ for $15 \%$ and $30 \% \mathrm{Ni} / \mathrm{Y}$ zeolite catalyst, respectively. The AC was derived from the multiplication of carbon flux and the integration of the curve fitting of methane conversion against reaction time using a proper third order polynomial equations with regression coefficients greater than 0.99 . The initial $\mathrm{AC}$ over $\mathrm{Ni} / \mathrm{Y}$ zeolite increases for temperatures of $500-650^{\circ} \mathrm{C}$, while deactivation time decreases when the reaction temperature increases from 550 to $600{ }^{\circ} \mathrm{C}$. The deactivation time at 500 and $650^{\circ} \mathrm{C}$ was almost identical and TAC was lower especially for $650^{\circ} \mathrm{C}$ when compared with 550 and $600{ }^{\circ} \mathrm{C}$ as shown in Table 2 . Interestingly, the highest TAC with $15 \% \mathrm{Ni} / \mathrm{Y}$ zeolite catalyst was almost equal to the lower TAC value with $30 \% \mathrm{Ni} / \mathrm{Y}$ zeolite catalyst as shown in Table 2 . In Fig. 2, we notice two rather asymmetrical deactivation processes. In the first stage, at the temperature range of $550-600^{\circ} \mathrm{C}$, a sluggish reduction of the decomposition rate and at 500 and $650^{\circ} \mathrm{C}$, the deactivation is faster and results in an absolute decrease of the catalytic activity. We speculate that at $500^{\circ} \mathrm{C}$, the carbon solubility is lower within the metal and the presence of polyaromatic hydrocarbon in the gas phase to start any type of carbon material growth is limited [14]. Chen et al. [15] have demonstrated that the aggravated saturated concentration of carbon materials was brought to the cata- lyst surface by low driving force of carbon diffusion which in turns, show a low carbon formation over the small size of Ni crystal sites which lead to a drastic deactivation of the catalysts. Additionally, the degree of carbon formation in zeolites is restricted by the limitations ascribed by the microporous structure; i.e., the loss of activity seems to be a space restriction as the microporous network becomes confined with carbon [7]. However, there is indication of that a decline in the rate of carbon accumulation with expanded reaction times can be associated to the poisoning of the active metal particle due to encapsulating carbon [7]. We can speculate further that at $650^{\circ} \mathrm{C}$, the free radical condensates or polyaromatic hydrocarbons are the building blocks of carbon materials. The free radical condensates are predicted to be a heap of carbon materials with differing quantities of hydrogen atoms [16]. Reilly and Whitten [16] pointed out that the free radical condensates are susceptible to quick rearrangement at $650{ }^{\circ} \mathrm{C}$, and owing to the way in which hydrogen inattentive by radical recombination, a diverse categories of carbon species can be generated. Structural and textural rearrangements of the catalyst particle are happened with the increase of carbon growth rate, which lead to form centers of growth in the carbon fibers [17]. In this scenario, after reduction of metallic nickel particles are saturated with carbon materials and their aggregate state may alter. The synopsis from this phase is to the alteration of nickel metallic particles sizes because of their schism and amalgamation.

In Table 2, the total methane conversion was determined by summing on the total methane conversion per initial Ni-supported Y zeolite catalyst mass. Inspection of yield data at times of 10 $60 \mathrm{~min}$, the TAC was enhanced for each run except $650^{\circ} \mathrm{C}$. The total methane conversion was also mimicked the same trends. For example, the total methane conversion was increased from 197.08 to $586.21 \mathrm{~mol} / \mathrm{g}_{\text {cat }}$ for temperature increased from 500 to $600{ }^{\circ} \mathrm{C}$ for $15 \% \mathrm{Ni} / \mathrm{Y}$ zeolite catalyst and afterwards, it started to decreased. The $30 \% \mathrm{Ni} / \mathrm{Y}$ zeolite catalyst was followed the same behavior. The weight of carbon deposit $\left(M_{c}\right)$ was increased as temperature increased except $650^{\circ} \mathrm{C}$ as shown in Table 2. For better assessment of the catalysts, $M_{c}$ was calculated (using Eq. (2)) in terms of the quantity of surface nickel due to the carbon formation rate was highly subjected to the quantity of $\mathrm{Ni}$ active sites. Nevertheless, a maximum carbon yield of $614.25 \mathrm{~g}_{\mathrm{c}} / \mathrm{g}_{\mathrm{Ni}}$ was observed after end of complete reaction at $600{ }^{\circ} \mathrm{C}$ with $30 \% \mathrm{Ni} / \mathrm{Y}$ zeolite catalyst. On the other hand, the highest $\mathrm{M}_{c}$ value for $15 \% \mathrm{Ni} / \mathrm{Y}$ zeolite was $157.54 \mathrm{~g}_{c} / \mathrm{g}_{\mathrm{Ni}}$; which is even lower than from the lower $\mathrm{M}_{\mathrm{c}}$ obtained with $30 \% \mathrm{Ni} / \mathrm{Y}$ zeolite catalyst at $500{ }^{\circ} \mathrm{C}$. Evidently, the TCD of methane over Ni/Y zeolite gave maximum amount of carbon yield in terms of the quantity of surface nickel at 550 and $600^{\circ} \mathrm{C}$. With increase of temperatures, the carbon yield reached a maximum point and then starts to decrease till the complete deactivation of the catalyst. Hernadi et al. [18] have reported the carbon production up to $1.6 \mathrm{~g}_{\mathrm{c}} / \mathrm{g}_{\text {cat }}$ for the cracking of an array of organic reactants over Co and Fe supported silica and zeolite. Park and
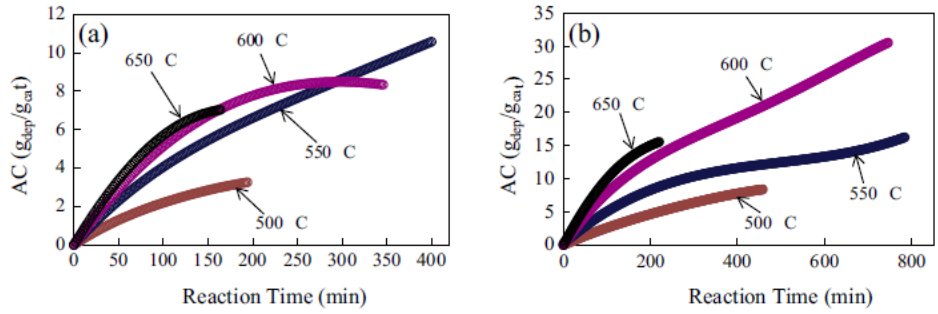

Fig. 2. Representation of accumulated carbon as a function of reaction time on stream for (a) $15 \% \mathrm{Ni} / \mathrm{Y}$ zeolite catalyst, and (b) $30 \% \mathrm{Ni} / \mathrm{Y}$ zeolite catalyst. 
Table 2

Experimentally observed the behavior of AC with total methane conversion for two types of $\mathrm{Ni} / \mathrm{Y}$ zeolite used catalyst.

\begin{tabular}{|c|c|c|c|c|c|c|c|c|}
\hline \multirow[t]{2}{*}{ Run no. } & \multirow[t]{2}{*}{$T\left({ }^{\circ} \mathrm{C}\right)$} & \multirow[t]{2}{*}{ Total methane conversion $\left(\mathrm{mol} / \mathrm{g}_{\mathrm{cat}}\right)$} & \multicolumn{3}{|c|}{$\begin{array}{l}\text { Behavior of average } \mathrm{AC}\left(\mathrm{g}_{\text {dep }} / \mathrm{g}_{\text {cat }}\right) \text { yield with } \\
\text { respect to time }\end{array}$} & \multirow{2}{*}{$\begin{array}{l}\mathrm{TAC}^{\mathrm{a}}\left(\mathrm{g}_{\mathrm{dep}} / \mathrm{g}_{\mathrm{cat}}\right) \\
\text { After end of complete reaction }\end{array}$} & \multirow{2}{*}{$\begin{array}{l}M_{c}(\%) \\
\text { After end } \\
\text { reaction }\end{array}$} & \multirow{2}{*}{$\begin{array}{l}M_{\mathrm{c}}\left(\mathrm{g}_{\mathrm{dep}} / \mathrm{g}_{\mathrm{Ni}}\right) \\
\text { of complete }\end{array}$} \\
\hline & & & $t=10 \mathrm{~min}$ & $t=26 \mathrm{~min}$ & $t=60 \mathrm{~min}$ & & & \\
\hline 1 & 500 & 197.08 & 0.151 & 0.378 & 0.80 & 193.91 & 428 & 66.56 \\
\hline 2 & 550 & 526.40 & 0.258 & 0.652 & 1.41 & 1248.97 & 1013 & 157.54 \\
\hline 3 & 600 & 586.21 & 0.323 & 0.82 & 1.78 & 1083.35 & 921 & 143.23 \\
\hline 4 & 650 & 405.47 & 0.378 & 0.958 & 2.08 & 372.39 & 684 & 106.37 \\
\hline 6 & 550 & 1047.30 & 0.476 & 0.92 & 1.80 & 4097.12 & 1567 & 366.12 \\
\hline 7 & 600 & 1242.54 & 0.484 & 1.22 & 2.70 & 6651.35 & 2629 & 614.25 \\
\hline 8 & 650 & 821.67 & 0.61 & 1.56 & 3.44 & 1075.19 & 1534 & 358.41 \\
\hline
\end{tabular}

a The TAC was determined by summing on the total instantaneous solid carbon accumulated per initial Ni-supported Y zeolite catalyst mass.

Keane [19] have remarked $70 \mathrm{~g}_{\mathrm{c}} / \mathrm{g}_{\mathrm{Ni}}$ carbon yield after $60 \mathrm{~min}$ reaction from the decomposition of ethylene at $600{ }^{\circ} \mathrm{C}$ using $\mathrm{Ni}$ supported $\mathrm{NaY}$ zeolite. Our carbon yields compare favorably with those generated from methane over supported Ni-alumina $\left(244 \mathrm{~g}_{\mathrm{c}} / \mathrm{g}_{\mathrm{Ni}}\right)$ and from over $\mathrm{Ni} / \mathrm{Cu} / \mathrm{Al}\left(585 \mathrm{~g}_{\mathrm{c}} / \mathrm{g}_{\mathrm{Ni}}\right)[20]$.

\subsubsection{Effect of VHSV on TCD of methane}

Fig. 3 shows the effect of volume hourly space velocity (VHSV) where percentage of methane conversion is typified as a function of reaction time for various VHSV, 8.57-60 $\mathrm{Lg}_{\text {cat }}^{-1} \mathrm{~h}^{-1}$, at $600{ }^{\circ} \mathrm{C}$ for different values of catalyst weight $(1-7 \mathrm{~g})$ along with constant methane flow rate of $1 \mathrm{~L} / \mathrm{min}$. It can be apparent from Fig. 3(a) that the deactivation rate of decomposition reaction is almost half of the Fig. 3(b) for VHSV range between 8.57 and $60 \mathrm{Lg}_{\text {cat }}^{-1} \mathrm{~h}^{-1}$. For example, at VHSV of $20 \mathrm{Lg}_{\text {cat }}^{-1} \mathrm{~h}^{-1}$, the catalytic activity endures a more than $10 \mathrm{~h}$ before falling almost zero with $30 \% \mathrm{Ni} / \mathrm{Y}$ zeolite catalyst, whereas, it was only more than $5 \mathrm{~h}$ for $15 \% \mathrm{Ni} / \mathrm{Y}$ zeolite catalyst.

It can be ensured from Fig. 3(a) and (b) that the methane conversion increased as VHSV and nickel concentration in Ni-Y catalysts increased. The more insightful observation is reintroduced that, with increasing VHSV, the time needed for catalyst deactivation gradually increases $[20,21]$. This is because a lower contact time results from a higher VHSV, the catalyst deactivation increased as the VHSV increased. The initial hydrogen yield was $65.90 \%$ at a low spatial velocity of $8.57 \mathrm{Lg}_{\text {cat }}^{-1} \mathrm{~h}^{-1}$ while its representative stability time was more than $5 \mathrm{~h}$ with $30 \%$ nickel concentration in Y zeolite catalyst. As compared with this result, $15 \% \mathrm{Ni} / \mathrm{Y}$ zeolite catalys gave initial hydrogen of $50.35 \%$, having stability time more than $2 \mathrm{~h}$ at the same spatial velocity of $8.57 \mathrm{Lg}_{\text {cat }}^{-1} \mathrm{~h}^{-1}$. Experimental observation marks that the studied range of VHSV still figured a high cata- lytic stability in originating hydrogen production. Using Ni/Y zeolite catalyst and different VHSV at $600{ }^{\circ} \mathrm{C}$, the following Table 3 is represented an inclusion of experimentally obtained results. From Fig. 3(a) and (b), it can be visualized that the initial methane conversion was decreased gradually with increasing VHSV, indicating a continuous diminishing in the hydrogen yield over the course of the reaction. As a matter fact that the methane conversion was noticeably increased from 23.10 to 50.40 vol\% as with decreased space velocity from 60 to $8.57 \mathrm{Lg}_{\text {cat }}^{-1} \mathrm{~h}^{-1}$ for $30 \% \mathrm{Ni} /$ Y zeolite catalyst. In case of $15 \% \mathrm{Ni} / \mathrm{Y}$ zeolite catalyst, these values increased from 16.65 to $33.92 \mathrm{vol} \%$ as shown in Table 3. This carried on to a lower constant hydrogen yield (below $7 \%$ ) whilst the complete deactivation of the catalyst.

It can be clearly obvious from Table 3 that ACFR and initial methane conversion move in reverse directions. Before catalysts completely deactivated, an optimum ACFR of 2.86 and $2.17 \mathrm{mmol} /$ ( $\mathrm{g}_{\text {cat }} \mathrm{min}$ ) can be obtained at space velocity of $20 \mathrm{Lg}_{\text {cat }}^{-1} \mathrm{~h}^{-1}$ due to a high stability is more pronounced for this experimental run for $30 \%$ and $15 \% \mathrm{Ni} / \mathrm{Y}$ zeolite catalysts, respectively. Moreover, a higher VHSV, increases the TCFR in the reported results for metal catalyst is not far away from our observation as reported in Table 3.

Fig. 4 reveals the methane decomposition rate $\left(R_{D}\right)$ in $(\mathrm{mmol} /$ (gcat min)) as a function of reaction time for both type of catalyst. The decomposition rate can be described as the ratio between product of molar flow rates of methane $(\mathrm{mmol} / \mathrm{min})$ and methane fractional decomposition to weight of the $\mathrm{Ni} / \mathrm{Y}$ zeolite catalyst [5]. From Fig. 4, it may be inferred that a high initial $R_{D}$ followed by a dramatic reduction. The initial methane reaction rate $\left(R_{o}\right)$ in ( $\mathrm{mmol} /($ gcat $\mathrm{min})$ ) was derived from the curve fitting of Fig. 4 using a proper $n$th order polynomial equations with regression coefficients greater than 0.99 and then equalizing the time to zero in
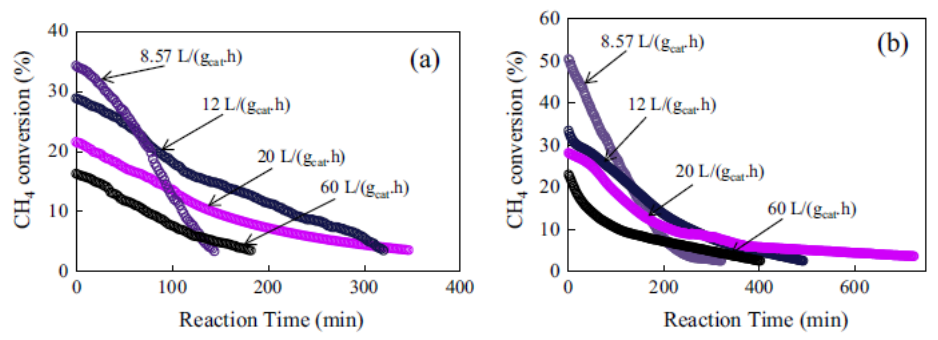

Fig. 3. Representation of methane conversion versus reaction time on the stream at different volume hourly space velocity for (a) $15 \% \mathrm{Ni} / \mathrm{Y}$ zeolite catalyst, and (b) $30 \% \mathrm{Ni} / \mathrm{Y}$ zeolite catalyst. 
Table 3

Summarized experimental results with different $\mathrm{VHSV}$ at $600^{\circ} \mathrm{C}$ using $\mathrm{Ni} / \mathrm{Y}$ zeolite catalyst.

\begin{tabular}{|c|c|c|c|c|c|c|c|c|}
\hline \multirow{2}{*}{$\begin{array}{l}\text { Run } \\
\text { no. }\end{array}$} & \multirow{2}{*}{$\begin{array}{l}\text { VHSV } \\
\left(\operatorname{Lg}_{\text {cat }}^{-1} h^{-1}\right)\end{array}$} & \multirow{2}{*}{$\begin{array}{l}\text { Initial } \mathrm{H}_{2} \text { yield } \\
\text { (\%) }\end{array}$} & \multirow{2}{*}{$\begin{array}{l}\Phi_{\mathrm{CH}_{4}} \\
(\%)\end{array}$} & \multirow{2}{*}{$\begin{array}{l}R_{o}(\mathrm{mmol} / \\
\left.\mathrm{g}_{\text {cat }} \mathrm{min}\right)\end{array}$} & \multicolumn{3}{|c|}{$\operatorname{TCFR}\left(\mathrm{mmol} /\left(\mathrm{g}_{\mathrm{cat}} \mathrm{min}\right)\right)$} & \multirow{2}{*}{$\begin{array}{l}\text { ACFR }\left(\mathrm{mmol} /\left(\mathrm{g}_{\mathrm{cat}} \mathrm{min}\right)\right) \\
\text { After end of complete } \\
\text { reaction }\end{array}$} \\
\hline & & & & & $\begin{array}{l}\text { At } \\
\text { time }=10 \mathrm{~min}\end{array}$ & $\begin{array}{l}\text { At } \\
\text { time }=26 \mathrm{~min}\end{array}$ & $\begin{array}{l}\text { At } \\
\text { time }=60 \mathrm{~min}\end{array}$ & \\
\hline \multicolumn{9}{|c|}{ With $15 \%$ Ni-supported Y zeolite catalysts } \\
\hline 1 & 8.57 & 50.35 & 33.92 & 3.62 & 22.89 & 51.52 & 104.84 & 2.59 \\
\hline 2 & 12 & 46.69 & 30.31 & 4.33 & 25.75 & 58.27 & 120.70 & 2.22 \\
\hline 3 & 20 & 36.32 & 22.11 & 5.29 & 31.90 & 70.78 & 139.94 & 2.17 \\
\hline 4 & 60 & 28.53 & 16.65 & 12.08 & 73.66 & 162.70 & 317.85 & 5.66 \\
\hline \multicolumn{9}{|c|}{ With $30 \%$ Ni-supported Y zeolite catalysts } \\
\hline 5 & 8.57 & 65.90 & 50.40 & 5.10 & 32.56 & 72.38 & 144.24 & 1.97 \\
\hline 6 & 12 & 49.77 & 33.43 & 4.70 & 29.30 & 66.56 & 139.13 & 2.28 \\
\hline 7 & 20 & 46.99 & 28.15 & 7.47 & 35.15 & 80.22 & 169.46 & 2.86 \\
\hline 8 & 60 & 34.85 & 23.10 & 16.33 & 71.23 & 161.03 & 334.81 & 6.91 \\
\hline
\end{tabular}
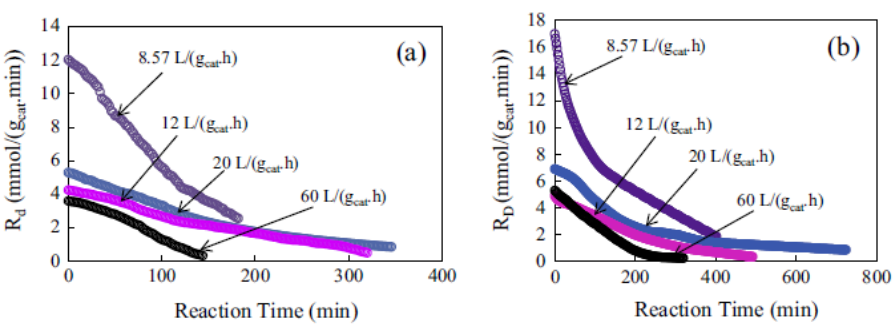

Fig. 4. Representation of methane decomposition rate as a function of time for (a) $15 \% \mathrm{Ni} / \mathrm{Y}$ zeolite catalyst, and (b) $30 \% \mathrm{Ni} / \mathrm{Y}$ zeolite catalyst.

the right hand side of the curve fitting equation. From Table 3 and Fig. 5 , it can be seen that $R_{0}$ increases with VHSV and it has a reverse and non-linear relevancy to the weight of Ni/Y zeolite catalysts. The higher concentration of nickel in Ni/Y zeolite causes a higher reduction for $R_{o}$. On the other hand, when higher weight of $\mathrm{Ni} / \mathrm{Y}$ zeolite was used, the yield of hydrogen was reduced because of the declines of contact time between the reactant molecule and catalyst, resulting from the increased VHSV. At the same time, the $R_{o}$ enhanced due to decreasing the influence of methane pressure drop that causes from the greater methane decomposition along with dilution by the formed hydrogen [22]. However, in Fig. 5, the upper curve indicates that $30 \% \mathrm{Ni} / \mathrm{Y}$ zeolite catalysts was produced maximum amount of hydrogen as well carbon nanofiber.

\subsection{Characterization of the catalysts}

\subsubsection{BET and TPD analysis}

In Table 4, we report that the BET surface and micropore area of the support materials were marginally reduced due to the proposi-

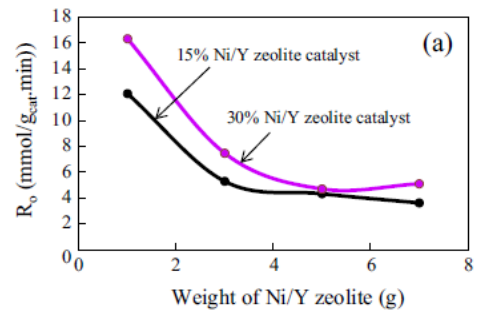

tion of nickel species onto the $Y$ zeolite. This may be interpreted the effect of higher pore blockage of $\mathrm{Y}$ zeolite pore channel resulted from the existence of highly concentrated small $\mathrm{Ni}^{2+}$ ions within the pore layout of the Y zeolite. Conversely, the catalyst surface area was changed to a small extent because of the intensity of metal loadings. This can be anticipated from the influence of partial blocking of $\mathrm{Y}$ zeolite pore channel caused the existence of metallic oxides on the surface of support. Fairly, the degree of interaction within the support and metal precursor is a function of maximum reduction temperature [15].

It has reported that a fewer quantities of weak acid sites were enwrapped to the raw Y zeolite [19]. The $\mathrm{Na}^{+}$ions of the Y zeolite were substituted by $\mathrm{Ni}^{2+}$ ions mimicked the hydrogen reduction to create Bronsted acid sites (protons) through the preparation method, resulting in acidity to a greatest extent. It has suggested that the reduction of nickel species in the impregnated catalyst was brought to a fewer surface acidity, which in turns fit in reposing the smaller particles [7]. Actually, the counter diffusion between the cations and protons of the metal is providing higher

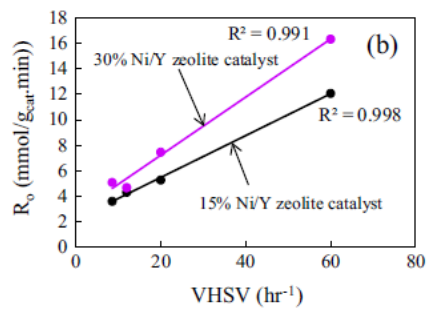

Fig. 5. Representation of initial methane decomposition versus (a) weight of Ni/Y zeolite, and (b) VHSV for both $15 \%$ and $30 \% \mathrm{Ni} / \mathrm{Y}$ zeolite catalysts at constant methane flow rate of $1 \mathrm{~L} / \mathrm{min}$. 
Table 4

\begin{tabular}{|c|c|c|c|c|c|c|c|c|}
\hline Sample & $\begin{array}{l}\text { Single point surface } \\
\text { area }\left(\mathrm{m}^{2} / \mathrm{g}\right)^{\mathrm{a}}\end{array}$ & $\begin{array}{l}\text { BET surface } \\
\text { area }\left(\mathrm{m}^{2} / \mathrm{g}\right)\end{array}$ & $\begin{array}{l}\text { Micropore } \\
\operatorname{area}^{\text {b }}\left(\mathrm{m}^{2} / \mathrm{g}\right)\end{array}$ & $\begin{array}{l}\text { Mesopore + external } \\
\operatorname{area}^{c}\left(\mathrm{~m}^{2} / \mathrm{g}\right)\end{array}$ & $\begin{array}{l}\text { Micropore } \\
\text { volume }\left(\mathrm{cm}^{3} / \mathrm{g}\right)^{d}\end{array}$ & $\begin{array}{l}\text { Total pore } \\
\text { volume }{ }^{e}\left(\mathrm{~cm}^{3} / \mathrm{g}\right)\end{array}$ & $\begin{array}{l}\text { Pore size } \\
(\mathrm{nm})\end{array}$ & $\begin{array}{l}\text { Average particle } \\
\text { size }(\mathrm{nm})\end{array}$ \\
\hline Y zeolite & 644.40 & 633.61 & 549.91 & 83.69 & 0.2684 & 0.388 & 2.452 & 4.73 \\
\hline $\begin{array}{l}30 \% \mathrm{Ni} / \mathrm{Y} \\
\quad \text { zeolite }\end{array}$ & 335.51 & 329.69 & 258.97 & 70.72 & 0.1266 & 0.237 & 2.88 & 9.90 \\
\hline \multicolumn{9}{|c|}{ With $15 \% \mathrm{Ni} / \mathrm{Y}$ zeolite catalysts } \\
\hline $600^{\circ} \mathrm{C}$ & 137.53 & 136.82 & 73.39 & 63.43 & 0.0356 & 0.201 & 5.87 & 21.92 \\
\hline $650^{\circ} \mathrm{C}$ & 173.90 & 172.78 & 94.27 & 78.50 & 0.0457 & 0.242 & 5.62 & 17.36 \\
\hline \multicolumn{9}{|c|}{ With $30 \% \mathrm{Ni} / \mathrm{Y}$ zeolite catalysts } \\
\hline $500^{\circ} \mathrm{C}$ & 158.38 & 157.25 & 91.90 & 65.35 & 0.044 & 0.211 & 5.39 & 19.07 \\
\hline $550^{\circ} \mathrm{C}$ & 100.30 & 100.23 & 44.39 & 55.83 & 0.0213 & 0.152 & 6.06 & 29.93 \\
\hline $600^{\circ} \mathrm{C}$ & 96.75 & 97.15 & 35.16 & 61.99 & 0.0167 & 0.138 & 7.49 & 30.87 \\
\hline $650^{\circ} \mathrm{C}$ & 104.31 & 103.69 & 51.69 & 52.00 & 0.0250 & 0.221 & 8.55 & 28.93 \\
\hline
\end{tabular}

a Represents the values calculated at a relative pressure $\left(P / P_{o}\right)$ of $\mathrm{N}_{2}$ equal to 0.251 .

${ }^{e}$ Represents the total pore volume evaluated from nitrogen uptake at a relative pressure $\left(P / P_{o}\right)$ of $\mathrm{N}_{2}$ equal to 0.99 .

numbers of metal ions into the pore mouths; resulting in form a zerovalent external metal phase followed a reduction. This type of counter diffusion is significantly accelerated when there is a high protonic concentration was present in the $\mathrm{Y}$ zeolite matrix. The assemblage process which is known to as responsible to form the particle growth may be disrupted because of the presence of high volume of cation density in the diffusion path of $\mathrm{Ni}$ content Thereat, the carbon growths is far more prevailing if the outer surface areas of $Y$ zeolite are covered by the metal particles and these sites are exclusively forcible if impregnation processes is employed to introduce the metal precursor [7]. This phenomenon may be anticipated by considering the Y zeolite structure. Structurally, zeolite $Y$ has 8 supercages, 8 sodalite cages and 16 hexagonal prism cages per unit cell [23]. It has pore mouth size of $0.74 \mathrm{~nm}$, and the supercage size has $1.3 \mathrm{~nm}$, suggesting that the void volume of $Y$ zeolite $\left(0.85 \mathrm{~nm}^{3}\right)$ is big enough to accommodate the dispersed metallic nickel in the supercages. Nevertheless, the production of carbon nanomaterials with a diameter below 1.3 is possible if $\mathrm{Ni}$ species lodged in the $\mathrm{Y}$ zeolite supercages. Indeed, such type of production is not promising energetically at all [7].

Table 4 shows that the surface areas subjected to the formation of CNFs are higher than that of the surface area subjected to the formation of carbon nanotube, but having a position between the amorphous carbon (surface area $=670 \mathrm{~m}^{2} / \mathrm{g}$ ) and the graphite (surface area $=7 \mathrm{~m}^{2} / \mathrm{g}$ ) [24]. With the raise of temperatures ramp from 500 to $600{ }^{\circ} \mathrm{C}$, the BET surface area decreased and afterwards, initiated to increase. The total pore volume and micropore volume has followed the same trends as BET surface area do until $600{ }^{\circ} \mathrm{C}$ and then onset to increase even though a smaller micropore volume was observed in all the samples. As a consequence, at a temperature greater than $600{ }^{\circ} \mathrm{C}$, the surface of carbon could be manifested mainly as mesoporous with an average pore diameter of 6 and $7.50 \mathrm{~nm}$ for $15 \%$ and $30 \% \mathrm{Ni} / \mathrm{Y}$ zeolite catalysts respectively.

To characterize the $\mathrm{NH}_{3}$ adsorbed on the various catalysts, the chromatograms are typified in Fig. 6. The peak location differs with a great extent of different metal loadings. It has been suggested that the characterization of the acid sites through $\mathrm{NH}_{3}$-TPD method does not have a close similarity to the quantitative measurement of the actual acidity strength due to the onset of diffusional limitations [25]. However, this type of measurement gives the qualitative indication of how $\mathrm{NH}_{3}$ molecules are strongly conjugated to the acid sites. At temperature ranges of $172-220,340-450$ and greater than $450{ }^{\circ} \mathrm{C}$ are assigned for the peak maxima of the weak, med-

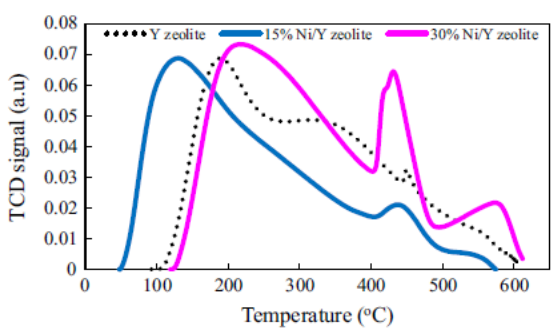

Fig. 6. Representation of NH3-TPD profile for selected sample catalyst.

ium, and strong acid sites, respectively. It has been reported that at lower temperature (weak acid sites), the quantity of adsorbed $\mathrm{NH}_{3}$ was always be higher than at higher temperature (strong acid sites) [26]. Additionally, one should note that when the metallic function is loaded into the $\mathrm{Y}$ zeolite, the acidity of $\mathrm{Y}$ zeolite decreases. This is reasonable because, through a catalyst preparation method, the small fraction of $\mathrm{OH}$ groups from the $\mathrm{Y}$ zeolite framework was eliminated by the metal salt precursors. This phenomenon is especially serious about the case of Ni/Y zeolite catalyst with the largest metal content, whose chromatograms has shifted by $30 \%$ from the original support and this metal content can be taken into consideration by means of few acid sites occupation by covered nickel species. With enhancing Ni content into $\mathrm{Y}$ zeolite, a slow decline in surface area was also visualized from Table 4. The increase of nickel species showed a slight impact on the maximum temperature corresponding to the desorption profile of $\mathrm{NH}_{3}$ as shown in Fig. 6. This would assuredly reflect that the $\mathrm{Ni}$ species marginally influenced the strength of the acid sites.

\subsubsection{XRD analysis}

The degree of structural order, longevity of catalyst and catalyst activity in fresh and deactivated samples is usually related with the apparent size of the crystallites determined by X-ray diffraction (XRD). The d-spacing and mean crystallite size along c axis is useful indicators in evaluating of catalyst performance during TCD of methane. Fig. 7 shows the XRD patterns for calcined and reduced catalysts for $15 \%$ and $30 \% \mathrm{Ni}$-supported Y zeolite catalyst. The diffraction peaks located at $2 \theta=10.098^{\circ}, 11.84^{\circ}$, and $15.59^{\circ}$ corre- 


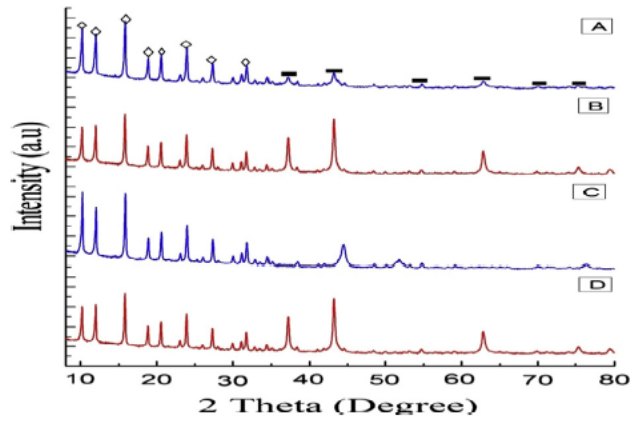

Fig. 7. Powder XRD patterns of fresh catalyst after calcination and reduction: ( $A$ and C) with $15 \% \mathrm{Ni} / \mathrm{Y}$ zeolite catalyst and (B and D) with $30 \% \mathrm{Ni} / \mathrm{Y}$ zeolite catalyst, respectively. Quadrilateral $(\diamond)$ and square $(\square)$ represents Y zeolite phase and NiO phase, respectively.

sponds to the d-spacing's of $8.752,7.464$ and $5.679 \AA$, respectively for calcined fresh catalysts as shown in Fig. 7(A) and (B). The positions of the diffraction peaks in the sample are in good agreement with those given in ICDS NO: 74-1192 for Y zeolite phase. It may be observed from Fig. 7(C) and (D) that the reduction of catalyst with $20 \%$ hydrogen in $\mathrm{N}_{2}$ at $600{ }^{\circ} \mathrm{C}$ was not sufficient to reduce $\mathrm{NiO}$ phase from the fresh catalyst. It has suggested that the decomposition of nickel nitrate from the preparation and calcination of catalysts could form the NiO phase in the fresh catalysts. In addition, this $\mathrm{NiO}$ phase interacting with supports on the surface of the catalyst, which creates a much more complex catalysis system. As a result, the active site for the adsorption and de-adsorption of gases may alter in the conjugated process, which likely shifts to a different reaction course during the TCD of methane.

Li et al. [27] have demonstrated that at the low temperature $\left(550^{\circ} \mathrm{C}\right)$, the reduction of catalyst is far from complete. However, after reduction of catalyst, the intensity of $\mathrm{Y}$ and $\mathrm{NiO}$ phase is slightly reduced in $30 \% \mathrm{Ni} / \mathrm{Y}$ zeolite (Fig. 7(D)) but significantly reduced in $15 \% \mathrm{Ni} / \mathrm{Y}$ zeolite (Fig. $7(\mathrm{C})$ ). The diffraction peaks at $2 \theta=37.44^{\circ}, 43.47^{\circ}$, and $63.20^{\circ}$ are corresponding to crystalline $\mathrm{NiO}$ phases (ICDS NO: 01-1239) and their interlayer distance are pointed out as $2.40,2.08$, and $1.47 \AA$ respectively. However, the mean diameter of $\mathrm{NiO}$ crystallites in $30 \% \mathrm{Ni} / \mathrm{Y}$ zeolite was determined of $39.54 \mathrm{~nm}$, while it was 41.69 for $15 \% \mathrm{Ni} / \mathrm{Y}$ zeolite attributing to the larger $\mathrm{NiO}$ particles lodged on the zeolite surface in before reduction. On the other hand, after reduction, the mean diameter of Ni crystallites was $34.84 \mathrm{~nm}$ for $30 \% \mathrm{Ni} / Y$ zeolite, while it was $36.57 \mathrm{~nm}$ for $15 \% \mathrm{Ni} / \mathrm{Y}$ zeolite attributing to the larger $\mathrm{Ni}$ particles anchored on the zeolite surface in after reduction.

At the temperature range of $500-650^{\circ} \mathrm{C}$, the X-ray diffraction profiles of deactivated catalysts in presence of $30 \%$ and $15 \% \mathrm{Ni} / \mathrm{Y}$ zeolite catalysts are shown in Figs. 8 and 9, respectively. As can be seen from Figs. 8 and 9 that, the broad diffraction peak at $2 \theta=26.34^{\circ}, 44.83^{\circ}, 54.23^{\circ}$, and $77.54^{\circ}$ are characteristic to the graphitic carbon (ICDS NO: 01-0640) and their $d$ values are defined as $3.38,2.02,1.69$ and $1.23 \AA$, respectively. The presence of metallic Ni phase (ICDS NO: 04-0850) in the deactivated catalyst gave the diffraction peak at $2 \theta=44.5^{\circ}, 51.84^{\circ}$, and $76.37^{\circ}$ and their corresponding " $d$ " values of $2.03,1.76$, and $1.24 \AA$, respectively.

From Fig. 8, it is apparent that, with increasing temperature from 500 to $650^{\circ} \mathrm{C}$, the graphitization intensity enhanced and altered to a higher $2 \theta$ angle which indicates a progressive graphitization of the CNFs. For example, the degree of graphitization in deactivated catalysts increased from $23.25 \%$ to $81.40 \%$ as temperature increased from 500 to $600{ }^{\circ} \mathrm{C}$ and afterwards, slightly reduced

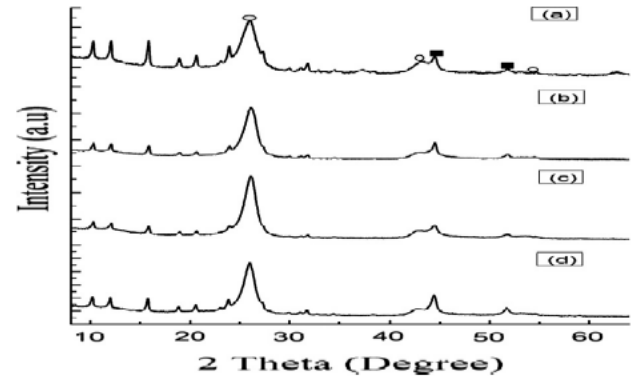

Fig. 8. Powder XRD patterns of used (a) $500{ }^{\circ} \mathrm{C}$, (b) $550{ }^{\circ} \mathrm{C}$, (c) $600^{\circ}$ and (d) $650{ }^{\circ} \mathrm{C}$ with $30 \% \mathrm{Ni} / \mathrm{Y}$ zeolite catalysts. Circle (o) and square (-) represents graphitic carbon phase and metallic $\mathrm{Ni}$ phase, respectively.

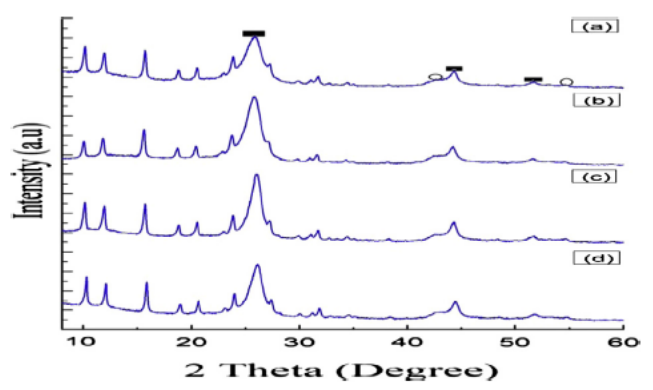

Fig. 9. Powder XRD patterns of used (a) $500^{\circ} \mathrm{C}$, (b) $550^{\circ} \mathrm{C}$, (c) $600^{\circ}$ and (d) $650^{\circ} \mathrm{C}$ with $15 \% \mathrm{Ni} / \mathrm{Y}$ zeolite catalysts. Circle (o) and square (ש) represents graphitic carbon phase and metallic Ni phase, respectively.

$(69.76 \%)$ at $650^{\circ} \mathrm{C}$ for $30 \% \mathrm{Ni} / \mathrm{Y}$ zeolite. One should note that at $600^{\circ} \mathrm{C}$, the degree of graphitization was almost identical to that of natural graphite $(0.335 \mathrm{~nm})$. Of beneficiary feedback from such graphitization is that it can positively be good for use in composites applications [7]. Table 5 shows the crystallite sizes of Ni metallic phases for both catalysts from XRD analysis.

Reported data in Table 5 reflects that at 500 and $550^{\circ} \mathrm{C}$, the mean diameter of metallic Ni crystallites after reaction were 44.18 and $44.08 \mathrm{~nm}$, while it was 39.20 and $39.47 \mathrm{~nm}$, respectively at 600 and $650{ }^{\circ} \mathrm{C}$ for $30 \% \mathrm{Ni} / \mathrm{Y}$ zeolite. Conversely, the mean diameter of metallic $\mathrm{Ni}$ crystallites in deactivated samples were $46.25 \mathrm{~nm}$, and $22.06 \mathrm{~nm}$ at 500 and $550{ }^{\circ} \mathrm{C}$, while it was $39.85 \mathrm{~nm}$, and $20.50 \mathrm{~nm}$ at 600 and $650{ }^{\circ} \mathrm{C}$, respectively for $15 \%$ $\mathrm{Ni} / \mathrm{Y}$ zeolite catalyst. It can be observed that the most of the Ni par-

Table 5

Crystallite sizes of deactivated catalysts after TCD of methane from XRD analysis at different temperatures.

\begin{tabular}{|c|c|c|c|}
\hline Samples & $\mathrm{Ni}(111)(\mathrm{nm})$ & $\mathrm{Ni}(200)(\mathrm{nm})$ & $\mathrm{Ni}(220)(\mathrm{nm})$ \\
\hline \multicolumn{4}{|c|}{ With 15\% Ni-supported Y zeolite } \\
\hline $500^{\circ} \mathrm{C}$ & 67.11 & 57.54 & 14.10 \\
\hline $550^{\circ} \mathrm{C}$ & 20.97 & 28.77 & 16.46 \\
\hline $600^{\circ} \mathrm{C}$ & 83.91 & 19.18 & 16.46 \\
\hline $650^{\circ} \mathrm{C}$ & 18.64 & 28.77 & 14.10 \\
\hline \multicolumn{4}{|c|}{ With $30 \%$ Ni-supported Y zeolite } \\
\hline $500^{\circ} \mathrm{C}$ & 83.91 & 34.53 & 14.10 \\
\hline $550^{\circ} \mathrm{C}$ & 33.55 & 49.32 & 49.37 \\
\hline $600^{\circ} \mathrm{C}$ & 55.92 & 28.77 & 32.92 \\
\hline $650^{\circ} \mathrm{C}$ & 27.96 & 57.54 & 32.92 \\
\hline
\end{tabular}

\section{Link to Full-Text Articles :}

